\title{
Pengaruh Two Step Annealing pada Struktur Kristal Nanopartikel Cobalt Ferrite Hasil Ko-presipitasi
}

\author{
Chomsatin Amalia, ${ }^{*}$ Suharyana, dan Budi Purnama ${ }^{\dagger}$ \\ Jurusan Fisika, Fakultas Matematika dan Ilmu Pengetahuan Alam, \\ Universitas Sebelas Maret \\ Jl. Ir. Sutami No.36 A Kentingan, Surakarta 57126
}

Intisari

\begin{abstract}
Pengaruh two step annealing terhadap struktur kristal nanopartikel cobalt ferit hasil ko-presipitasi telah dikaji pada penelitian ini. Hasil FTIR menunjukkan bahwa cobalt ferit berstruktur spinel terbentuk pada sekitar daerah $\mathrm{k}=590 \mathrm{~cm}^{-1}$. Perlakuan temperatur pre-heating pada skema two step annealing menurunkan transmitansi namun tidak menggeser angka gelombang terbentuknya cobalt ferit. Konfirmasi struktur kristal menggunakan XRD menegaskan bahwa cobalt ferit terbentuk berstruktur kubus fcc dengan intensitas puncak maksimum terjadi pada sudut $2 \theta=35,7^{\circ}$. Hasil analisis Scherrer menunjukkan bahwa perlakuan pre-heating pada skema two step annealing dapat memodifikasi ukuran butiran kristalin sampel cobalt ferit yang dihasilkan.
\end{abstract}

\begin{abstract}
Two step annealing dependence on crystal structure in co-precipitated cobalt ferrite nanoparticles have been examined. The FTIR results showed that the cobalt ferrite spinel structure was observed at $\mathrm{k}=590 \mathrm{~cm}^{-1}$. Treatment of pre-heating temperature has lowered transmittance and has not shifted wave numbers of cobalt ferrite vibration. Confirmation of crystalline structure using XRD indicated that fcc cobalt ferrite was seen at diffraction peak of $2 \theta=35,7^{\circ}$. Scherer analysis showed that pre heating treatment can modify crystal size of cobalt ferrite sample.
\end{abstract}

KATA KUNCI: Co-precipitation, $\mathrm{CoFe}_{2} \mathrm{O}_{4}$, crystallite size, nanoparticle

\section{PENDAHULUAN}

Nanopartikel ferrite merupakan material magnetik yang memiliki peran penting dengan sifat magnetik dan elektriknya yang khusus $[1,2]$. Cobalt ferrite $\left(\mathrm{CoFe}_{2} \mathrm{O}_{4}\right)$ nanopartikel secara khusus menarik karena anisotropi yang tinggi, koersivitas tinggi, magnetisasi saturasi moderat, kestabilan kimia dan struktural yang baik pada temperatur tinggi [3-5]. $\mathrm{CoFe}_{2} \mathrm{O}_{4}$ ini juga dapat dihadirkan dalam ukuran butiran kristalit orde nanometer sehingga seringkali disebut dengan istilah nanopartikel cobalt ferrite [6]. Keunggulan karakteristik ini membuat nanopartikel $\mathrm{CoFe}_{2} \mathrm{O}_{4}$ berpotensi untuk aplikasi elektronika yaitu media perekaman magnetik dengan kerapatan tinggi [7].

Banyak ragam metode preparasi yang dikembangkan dalam mensintesis nanopartikel magnetik, antara lain sol-gel [8, 9], hydrothermal synthesis [10], ball milling [11], chemical precipitation [12] dan citrate-gel method [13], thermolysis [14], solvothermal [15], combustion [16], microemulsion [17] and citrate methods [18]. Ragam metode ini menghasilkan distribusi ukuran butiran kristalit yang relatif sempit jika dilakukan pada kondisi lingkungan normal [19]. Terlebih, ketergantungan temperatur pengendapan terhadap dis-

\footnotetext{
*E-MAIL: chomsatin13@gmail.com

${ }^{\dagger}$ E-MAIL: bpurnama@mipa.uns.ac.id
}

tribusi ukuran butirnya nanopartikel $\mathrm{CoFe}_{2} \mathrm{O}_{4}$ pada metode ko-presipitasi juga telah dilaporkan [20].

Pada penelitian ini, nanopartikel cobalt ferrite disintesis dengan teknik ko-presipitasi. Perlakuan pre-heating pada prosedur two step annealing diharapkan dapat memvariasi ukuran butiran kristalit. Kemudian sampel dikarakterisasi dengan FTIR untuk mengamati frekuensi resonansi terbentuknya gugus oksida cobalt ferrite. Akhirnya, struktur kristal sampel yang terbentuk dikonfirmasi dengan menggunakan xrd.

\section{METODE EKSPERIMEN}

Sintesis nanopartikel $\mathrm{CoFe}_{2} \mathrm{O}_{4}$ dibuat menggunakan metode ko-presipitasi. Bahan utamanya adalah $\mathrm{Fe}\left(\mathrm{NO}_{3}\right)_{3} .9 \mathrm{H}_{2} \mathrm{O}$ sebanyak $0,002 \mathrm{~mol}$ dan $\mathrm{Co}\left(\mathrm{NO}_{3}\right)_{2} \cdot 6 \mathrm{H}_{2} \mathrm{O}$ 0,01 mol sebagai penyedia ion $\mathrm{Co}^{2+}$ dan $\mathrm{Fe}^{3+}$. Sintesis dilakukan dengan mencampurkan $\mathrm{Fe}\left(\mathrm{NO}_{3}\right)_{3}$ dan $\mathrm{Co}\left(\mathrm{NO}_{3}\right)_{2}$ dalam aquades $(200 \mathrm{ml})$ dan diaduk hingga larutan menjadi homogen. Kemudian larutan tersebut dititrasi kedalam larutan $\mathrm{NaOH}(4,8 \mathrm{M})$ sambil diaduk menggunakan magnetic stirrer $(1000 \mathrm{rpm})$ dengan temperatur $95^{\circ} \mathrm{C}$. Setelah larutan terbentuk, dilakukan proses pengendapan didalam gelas beker yang kemudian hasil endapan ini disebut precursor. Langkah berikutnya adalah pencucian precursor menggunakan aquades dan aceton secara berulang-ulang hingga 


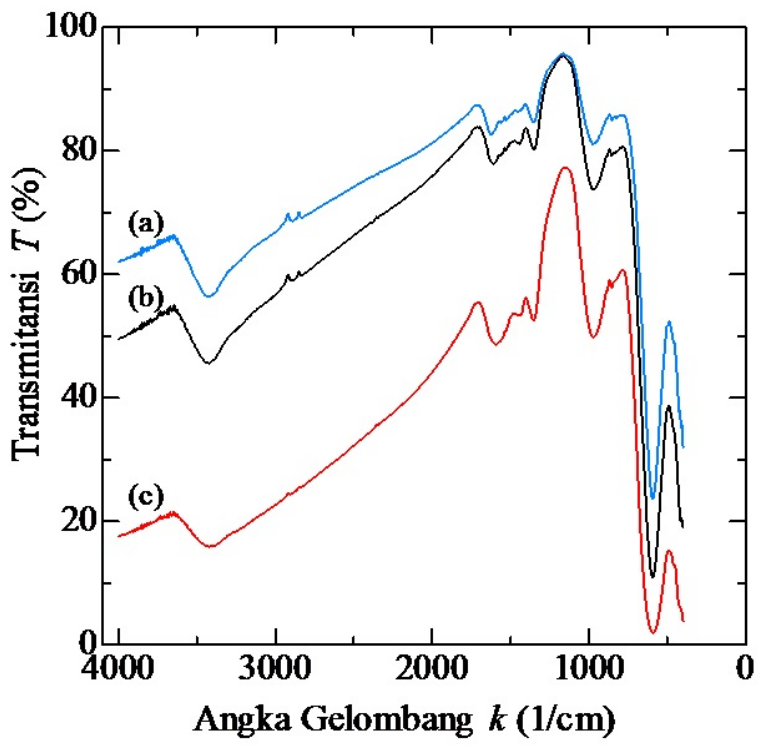

Gambar 1: Hasil karakteristik FTIR sampel $\mathrm{CoFe}_{2} \mathrm{O}_{4}$ untuk annealing pada temperatur (a) $600^{\circ} \mathrm{C}$ selama 4 jam dan dengan didahului variasi temperatur pre-heating (2 jam) berturut-turut (b) $200^{\circ} \mathrm{C}$ dan (c) $400^{\circ} \mathrm{C}$.

bersih. Hasil endapan precursor ini kemudian dikeringkan dalam oven temperatur $100^{\circ} \mathrm{C}$ selama 12 jam sehingga didapat sampel cobalt ferrite $\mathrm{CoFe}_{2} \mathrm{O}_{4}$.

Untuk memodifikasi ukuran butiran kristalit, maka dilakukan perlakuan two step annealing. Prosedur dimulai dengan pre-heating selama 2 jam kemudian dilanjutkan anneling pada temperatur $600^{\circ} \mathrm{C}$ selama 4 jam pada keadaan atmosfer. pre-heating dimodifikasi temperatur 200 dan $400^{\circ} \mathrm{C}$ serta satu sampel tanpa melalui prosedur ini sebagai sampel kendali. Sampel $\mathrm{CoFe}_{2} \mathrm{O}_{4}$ yang dihasilkan berupa serbuk kemudian dikarakterisasi menggunakan fourier transform infra red (FTIR) dan X-ray diffraction (XRD).

\section{HASIL DAN PEMBAHASAN}

Gambar 1 menunjukan hasil karakterisasi FTIR sampel cobalt ferrite hasil ko-presipitasi. Teramati dengan jelas pada gambar terdapat karakteristik serapan bersesuaian dengan bilangan gelombang k. Karakteristik spektral FTIR pada k $=3400$ dan $1521 \mathrm{~cm}^{-1}$ adalah mode rentangan dan vibrasi ikatan $\mathrm{H}-\mathrm{O}-\mathrm{H}$ bebas, yaitu molekul air terserap pada angka gemolang ini [21]. Selebihnya, terlihat jelas bahwa pada angka gelombang kecil (pita frekuensi lebih tinggi) yaitu sekitar $600 \mathrm{~cm}^{-1}$ dan angka gelombang lebih kecil lagi adalah sekitar $400 \mathrm{~cm}^{-1}$ terdapat karakteristik puncak serapan yang dihubungkan salah satunya dengan instrinsic stretching vibrations pada bagian tetrahedral dan logam octahedral pada angka gelombang lebih kecil lagi [21, 22]. Pita serapan yang diamati pada batas pembentukan struktur spinel ini disinyalir sebagai cobalt ferrite yaitu terbentuk pada $\mathrm{k}=590 \mathrm{~cm}^{-1}$. Perlakuan pre-heating pada perlakuan two step annealing sampel

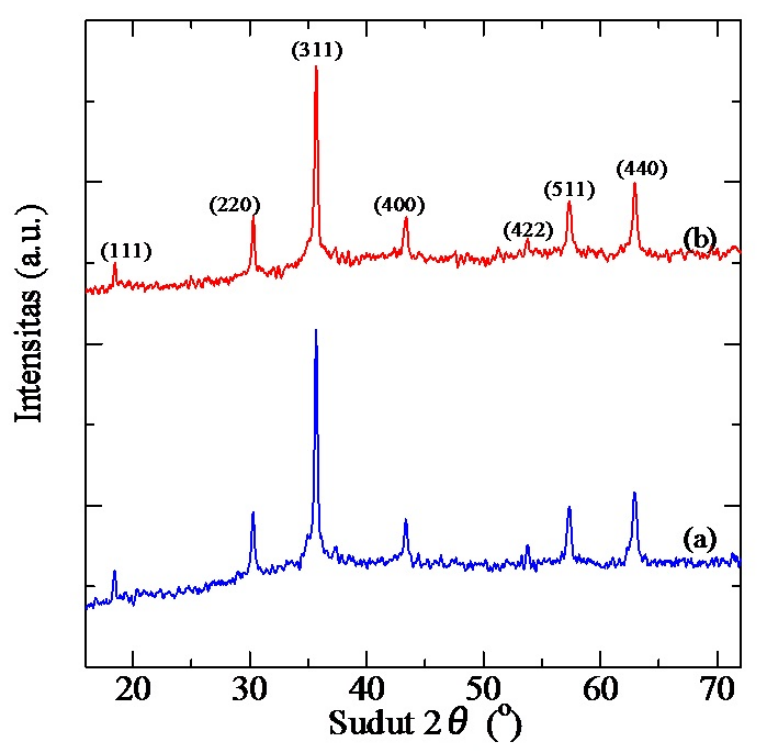

Gambar 2: Karakteristik spektral XRD sampel $\mathrm{CoFe}_{2} \mathrm{O}_{4}$ pada annealing (a) $600^{\circ} \mathrm{C} 4$ jam dan two step annealing $400^{\circ} \mathrm{C}$ (2 jam) $600^{\circ} \mathrm{C}(4 \mathrm{jam})$.

tidak menggeser puncak karakterisasi serapan, namun menurunkan prosentasi transmitansi sampel. Saat sampel tidak ada perlakuan pre-heating, transmitansi sampel sekitar $60,0 \%$ diperoleh saat $\mathrm{k}=4000 \mathrm{~cm}^{-1}$. Kemudian nilai transmitansi pada angka gelombang yang sama berturut-turut turun menjadi $49,5 \%$ untuk temperatur pre-heating $200^{\circ} \mathrm{C}$ dan tinggal $17,6 \%$ untuk temperatur pre-heating $400^{\circ} \mathrm{C}$.

Untuk konfirmasi realisasi cobalt ferrite yang terbentuk, maka sampel dikarakterisasi struktur kristalnya dengan XRD. Sedangkan ukuran butiran sampel $\mathrm{CoFe}_{2} \mathrm{O}_{4}$ dihitung menggunakan rumus Scherrer dari puncak tertinggi

$$
t=\frac{k \lambda}{D \cos \theta}
$$

dengan $\mathrm{t}$ adalah ukuran butir kristalit, $\mathrm{k}$ adalah konstanta Scherrer $(0,9), \lambda$ adalah panjang gelombang sinar-X yang digunakan, $\theta$ adalah sudut Bragg, D adalah lebar setengah puncak (Full Width at Half Maximum FWHM) dalam radian. Hasil spektrum XRD sampel $\mathrm{CoFe}_{2} \mathrm{O}_{4}$ hasil sintesis kopresipitasi ditampilkan pada Gambar 2. Kesesuaian puncak spektral dengan indeks Miller dianalisis menggunakan ICDD nomor 221086. Sampel a adalah sampel hasil annealing temperatur $600^{\circ} \mathrm{C}$ selama 4 jam tanpa perlakuan pre-heating dan sampel $\mathrm{b}$ adalah hasil two step annealing dengan pre-heating temperatur $400^{\circ} \mathrm{C}$ selama 2 jam dilanjutkan annealing temperatur $600^{\circ} \mathrm{C}$ selama 4 jam. Oksida lain tidak hadir sebagai puncak baru akibat pre-heating. Demikian juga halnya tidak terjadi pergeseran puncak spektrum. Namun two step anneling hanya mempengaruhi tinggi karakteristik puncak spektrum. Lebih lanjut, jika tinggi puncak tertinggi digunakan untuk identifikasi kristalinitas, maka ukuran butiran dapat dihitung menggunakan Pers.(1) berdasar keseuaian sudut puncak tertinggi. Hasil perhitungan menghasilkan ukuran butiran sebesar 
$25,3 \mathrm{~nm}$ jika sampel cobalt ferrite di-annealing pada temperatur $600^{\circ} \mathrm{C}$ selama 4 jam. Ukuran butiran kristalit menjadi $30,4 \mathrm{~nm}$ jika sampel dilakukan perlakuan two step annealing. Untuk menjadi perhatian bahwa perhitungan dengan analisis Scherrer ini dengan asumsi sumbangan pelebaran spektral XRD didominasi oleh sebaran butiran kristalit sampel dengan mengabaikan sumbangan dari slit sumber XRD.

\section{SIMPULAN}

Analisis efek two step annealing terhadap struktur nanopartikel cobalt ferit hasil ko-presipitasi telah dilaporkan pada penelitian ini. Hasil analisis FTIR menunjukkan bahwa cobalt ferit berstruktur spinel terbentuk pada sekitar daerah $\mathrm{k}=590$ $\mathrm{cm}^{-1}$. Perlakuan temperatur pre-annealing pada skema two step annealing menurunkan transmitansi FTIR namun tidak menggeser angka gelombang terbentuknya cobalt ferit. Konfirmasi struktur kristal menggunakan xrd menegaskan bahwa cobalt ferit terbentuk berstruktur kubus fcc dengan intensitas puncak maksimum terjadi pada sudut $2 \theta=35,7^{\circ}$. Hasil analisis Scherer menunjukkan bahwa perlakuan pre-heating pada skema two step annealing dapat memodifikasi ukuran butiran kristalin sampel cobalt ferit yang dihasilkan.
[1] E.A. Setiadi, $d k k$., Indonesian Journal of Applied Physics, 3(1), 55-62 (2013).

[2] H. Kumar, et al., International Journal of Electrical and Electronics Engineering, 2, 59-66 (2013).

[3] N. Moumen, P. Bonville, M.P. Pileni, J. Phys. Chem. 100, 1441014416 (1996).

[4] S.J. Stewart, et al., Phys. Rev., B 75, 073408 (2007).

[5] S. Ayyappan, J. Philip, B. Raj, J. Phys. Chem,. C 113, 590-596 (2009).

[6] K. Maaz, et al., Journal of Magnetism and Magnetic, 321, 18381842 (2009).

[7] R Skomski, J. Phys: Condens. Matter, 15, 1-56, (2003).

[8] H. Cui, Y. Jia, W. Ren, W. Wang, J. Sol-Gel Sci. Technol., 55, 36-40 (2010).

[9] E. Veena Gopalan, et al., J. Alloys Comp., 485, 711-717 (2009).

[10] S.C. Goh, et al., Mater. Chem. Phys., 120, 31-35 (2010).

[11] P.M. Richard, et al., Mater. Char., 61, 1317-1320 (2010).

[12] J. Wang, et al., J. Alloys Comp., 450, 532-539 (2008).
[13] R.S. Turtelli, et al., J. Magn. Magn. Mater., 320, 2445-2457 (2008).

[14] P. Ravindranathan, K.C. Patil, Am. Ceram. Soc. Bull., 66, 688692 (1987).

[15] S. Sun, et al., J. Am. Chem. Soc., 126, 273-279 (2004).

[16] N. Bao, et al., J. Am. Chem. Soc., 129, 12374-12375 (2007).

[17] K. Maaz, et al., J. Magn. Magn. Mater., 308, 289-295 (2007).

[18] L. Cabrera, et al., Electrochim. Acta, 53, 3436-3441 (2008).

[19] A.H. Lu, E.L. Salabas, and F. Schth, Magnetic Nanoparticles; Synthesis, Protection, Functionalization and Application (Angew. Chem. Int. Ed., Wiley-VCH Verlag GmbH \& Co. KGaA, Weinheim, 46, 1222-1244, 2007).

[20] Y.I. Kim, D. Kim, and C.S. Lee, Physica B, 337, 42-51 (2003).

[21] Y. Köseöglu, et al., Journal of Nanoparticle Research, 13, 22352244 (2010).

[22] R.D.D. Waldron, Physical Review, 99, 1727-1735 (1955). 